\title{
IoT-Based Kobela Teaching Aid for Mathematics Learning Multiplication and Division Materials for Grade II Elementary School Students
}

\author{
Muhammad Ilham Setiawan, Novian Anggis Suwastika, Sidik Prabowo \\ Informatics, Informatics, Telkom University, Bandung, Indonesia \\ Email: 1,*milhamsetiawan@ @student.telkomuniversity.ac.id , ${ }^{2}$ anggis@ telkomuniversity.ac.id, \\ 3pakwowo@telkomuniversity.ac.id \\ Corresponding Author Email: milhamsetiawan@student.telkomuniversity.ac.id
}

\begin{abstract}
Kotak Belajar Ajaib (Kobela) is props for elementary school math class II which can help learn to calculate multiplication and division. Based on research conducted by Sugeng Harnanto, Kobela can improve concentration, increase creativity and student learning outcomes. This tool has been tested in low-grade learning and extracurricular learning activities. The average student success in learning without using teaching aid is $54.56(56.77 \%)$, after using teaching aid the average learning success rate reaches 90.52 (94.19\%). The level of mastery learning for Basic Competencies: 3.1 Doing Multiplication of Two Numbers have increased by 37.42. In previous studies, the application of Kobela teaching aid in all learning activities was still manual-based. Potential or opportunities for development, especially for reading assessments and automatic data storage are possible to be achieved by implementing the Internet of Things (IoT). In this study, Kobela was built which implements IoT technology for reading, assessment, and recording based on learning activities. Then evaluate the system by testing the functionality of all the learning activities. From the test results, it was found that the system was running $100 \%$ by the specified function. The results of system performance testing in terms of sensor readings are on average 3 seconds with 8 Watt room lighting conditions and the average value of the assessment accuracy is 84 .
\end{abstract}

Keywords: Kobela; IoT; Arduino; Color Sensor; System Performance

\section{INTRODUCTION}

Learning is a process of interaction between students or students with educators or teachers and learning resources in a learning environment that includes teachers and students exchanging information [1], [2]. Learning must be planned in such a way that students can achieve the objectives of the learning. The learning method is an important aspect of an educational study. And each individual must have a different learning method that is interesting and easy to use. For individuals learning, methods do not need to be difficult and long-winded. Learning does not necessarily have to follow methods that are important to attract and easily understand the material [3], [4].

Teaching aid is everything that can be used to explain learning concepts from material that is abstract to be real and clear so that it can stimulate the thoughts, feelings, attention, and interests of students which leads to the process of learning [5], [6]. Educational aid are tools that can be absorbed by the eyes and ears with the aim of helping teachers to make the teaching and learning process more effective and efficient. One example of teaching aid that can be used to assist the learning process is the Kotak Belajar Ajaib (Kobela). Kobela is a teaching aid for elementary school math class II that can help learn to count multiplication and division [7].

Assessment is automatically carried out with the help of technology, namely the Internet of Things (IoT) which detects all activities embedded in objects and is able to interact through the network and be connected [8]. The application of Kobela teaching aid in previous studies was still carried out manually or by the teacher, this could lead to errors in the assessment due to the teacher's unfocused condition and incorrect notes. So in this research, development was carried out especially for reading assessments and automatic data storage by implementing IoT. The device that was built can be used by students in carrying out learning activities according to instructions by answering questions on Kobela.

This system analyzes the performance and functionality of the system based on the parameters of the reading speed and the accuracy of the assessment. This is necessary for the suitability of the output in terms of speed and accuracy of sensors that will send data to ThingSpeak as an IoT platform.

\section{RESEARCH METHODOLOGY}

\subsection{Methodology}

The research methodology shown in Figure 1 is a research stage that can be interpreted as a series of processes from start to finish. The first process focuses on the study of the research literature that has been carried out previously, especially research related to the designed tool. After conducting a literature study, the system design is carried out in the next process. The system design discusses what equipment is used and implementation is carried out. The next process discusses the test plan of the system being built in terms of its function and performance. The results of the test plan were analyzed according to the parameters that have been determined until the conclusion stage is completed. 


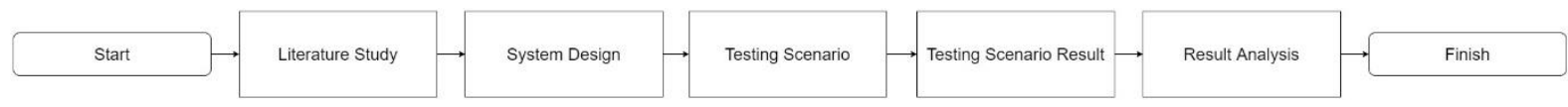

Figure 1. Research methodology

\subsection{Literature Study}

a) The research has been conducted by Sugeng Harnanto with the title "Alat Peraga Kotak Belajar Ajaib (Kobela) dalam Pembelajaran Matematika Materi Perkalian dan Pembagian Sekolah Dasar" [7]. The researcher stated that the purpose of the Kobela tool was (1) to increase student's concentration/attention, (2) to increase student's creativity, (3) to improve student's learning outcomes, and (4) to please students. This tool has been tested in low-grade learning and extracurricular learning activities. The success of students in learning before using the tool averaged $54.56(56.77 \%)$, but after using the tool the success rate reached an average of 90.52 $(94.19 \%)$.

b) The research has been conducted by Rauzatun Adrami \& Zulfan Martunis with the title "Pengaruh Media Kotak Ajaib Terhadap Motivasi Belajar Sejarah Siswa Kelas XI IPS SMA Negeri 1 Padang Tiji Kabupaten Pidie" [9]. It is stated that this research uses a mixed methods approach or a combination approach (quantitative and qualitative) with an experimental research type. The average score of students in the experimental class using Kobela's media was 83.5, while the control class which was still using conventional learning models had an average score of 70.4. Based on the results of research using conventional methods, the level of motivation in students got an average value of $29.67 \%$. After using the Kobela learning media, the average value of history learning motivation in class XI increased to $94.34 \%$. The results of this study indicate that learning history using Kobela media can increase student's learning motivation.

c) Based on two previous studies, Kobela teaching aid have not been integrated with IoT, especially in the field of education. At this time all activities carried out by humans have begun to be affected by technological phenomena, especially in the IoT field. This has led to an increase in access to technology-enabled learning content. The application of education through electronics with the IoT field is the use of IoT in the learning process [10].

d) Based on research conducted by Rahmanto, Irvan Naufali, Novian Anggis Suwastika \& Rahmat Yasirandi with the title "How Can IoT Applicable to Practice Gross Motor Skill Through Hopscotch Game?" discusses motor development in children aged 4-6 years using the hopscotch game or commonly called engklek [11].

e) In addition, research conducted by Jati, Riyan Kuncoro, Novian Anggis Suwastika \& Rahmat Yasirandi with the title "Hopscotch game to support stimulus in children's gross motor skill using IoT" discusses gross motor stimulation of children using hopscotch games by utilizing IoT technology [12]. The next research using IoT for children's education was conducted by Seiba Shonia, Novian Anggis Suwastika, and Rahmat Yasirandi with the title "Bag Toss Game based on Internet of Education Things (IoET) for the Development of Fine Motor Stimulation in Children 5-6 Years Old" discusses building a system that aims to help stimulate and train children's motor development in aspects of hand-eye coordination [13]. The latest research that is still related to the use of IoT for children's education was carried out by Halim Wajdi, Novian Anggis Suwastika, and Rahmat Yasirandi with the title "IoT Architecture that Supports the Stimulation of Gross 13 Motor Development in Children Aged 5-6 Years Using DropBox Game" discusses how to stimulate children's motor development using the DropBox game [14].

f) The research that has been done by Dwi Ratnawati and Vivianti with the title "Alat Pendeteksi Warna Menggunakan Sensor Warna TCS3200 Dan Arduino Nano" discusses a tool to detect several colors using TCS3200 and Arduino Nano sensors. This color sensor is used to distinguish colors from the captured data. On the TCS3200 color sensor, there are I/O PORTs SDA and SCL which serve as interfaces to the Arduino IDE. Collecting data from each color object needs to be brought closer to the sensor so that the sensor can be activated [15].

\subsection{Kobela}

Kobela is an acronym for the Kotak Belajar Ajaib, which is a small box used for learning (gaining knowledge) that is considered a new or strange item in which there is a human-driven tool. The Kobela props that were made have the objectives of increasing concentration/attention, increasing creativity, improving learning outcomes, and pleasing students. In every opportunity, especially mathematics learning should begin with the introduction of problems that are appropriate to the situation (contextual problems). By posing contextual problems, students are gradually guided to master mathematical concepts. Schools are expected to use information and communication technology such as computers, teaching aid, or other media to increase the effectiveness of learning. Other media that can be used to increase the effectiveness of learning, especially in low-grade mathematics learning, are Kobela props in the form of a box and cards [6] 
JURNAL MEDIA INFORMATIKA BUDIDARMA

Volume 5, Nomor 3, Juli 2021, Page 1142-1149

ISSN 2614-5278 (media cetak), ISSN 2548-8368 (media online)

Available Online at https://ejurnal.stmik-budidarma.ac.id/index.php/mib DOI 10.30865/mib.v5i3.3107

\subsection{System Design}

This section discusses flowchart diagrams, system architecture, tool representation, and test scenarios.

\subsubsection{Flowchart Diagrams}

Figure 2 represents a flowchart on the Kobela system that starts when playing activities are carried out, then the activity is recorded by sensors and sent to the IoT platform. In this study, in addition to the activity recording process, the system also allows measuring its performance based on predetermined parameters.

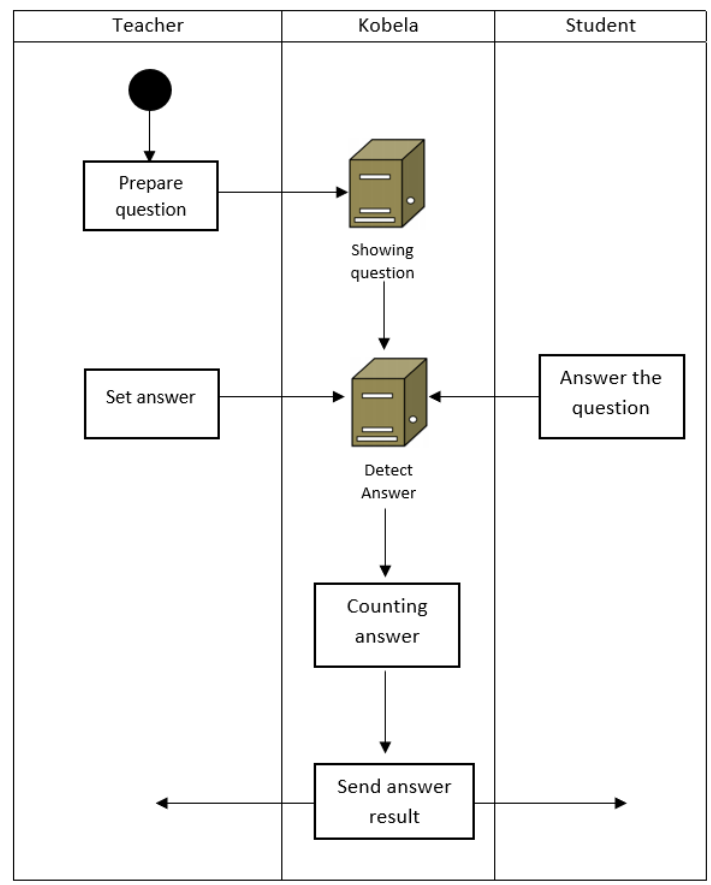

Figure 2. Flowchart Diagrams

\subsubsection{System Architecture}

Figure 3 represents the system architecture that was built by describing how the system works on user involvement, props applied, devices used, and communication of data information from start to finish and sent via the internet. Several studies related to uploading sensor data to the internet are ThingSpeak based sensing and monitoring system for IoT [16] and IoT-based environmental monitoring systems using Arduino and ThingSpeak [17].

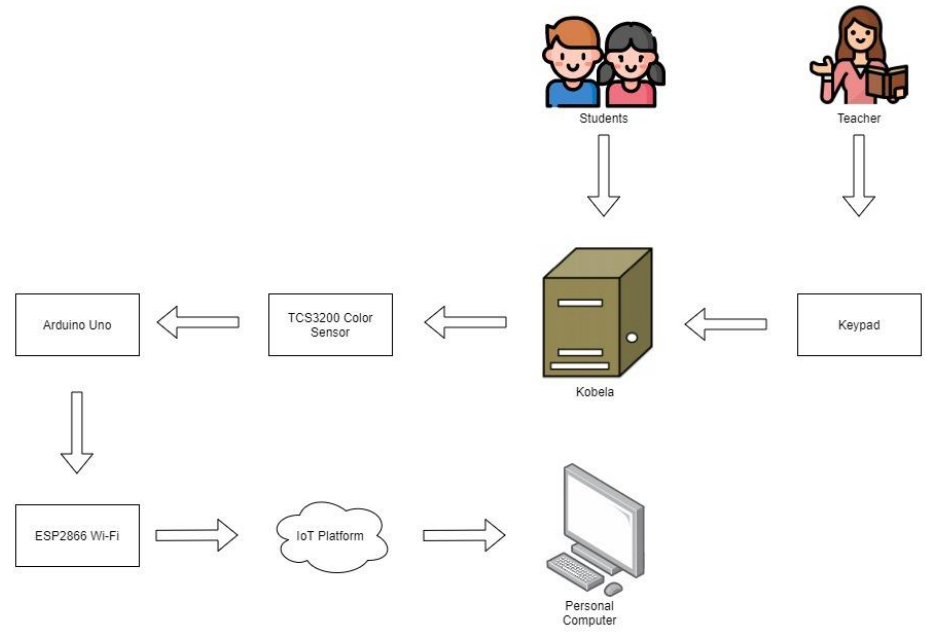

Figure 3. System Architecture

The teacher arranges the answers when students start doing activities on Kobela props. Each answer answered by these students is an input that is processed by the system. Furthermore, if the game has finished, then the output on the serial monitor is sent to the IoT platform using the internet. 
JURNAL MEDIA INFORMATIKA BUDIDARMA

Volume 5, Nomor 3, Juli 2021, Page 1142-1149

ISSN 2614-5278 (media cetak), ISSN 2548-8368 (media online)

Available Online at https://ejurnal.stmik-budidarma.ac.id/index.php/mib DOI 10.30865/mib.v5i3.3107

\subsubsection{Tool Representation}

The representation of the tool on the device that was built involves several hardware components as well as the device circuit block diagram as shown in Figure 4 and Figure 5.

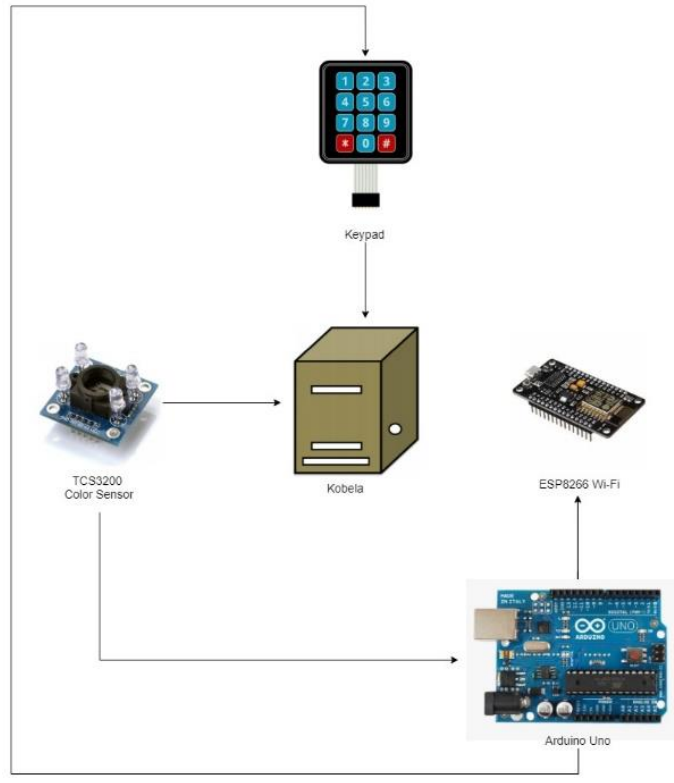

Figure 4. Tool Representation

The TCS3200 color sensor in the Kobela props functions as a color paper detector. Arduino uno which is connected to the color sensor serves to validate the accuracy between the color paper and the answer data. The results of the data validation are sent to the IoT platform via the internet. The keypad in the kobela props functions as an interface between the teacher and the device.

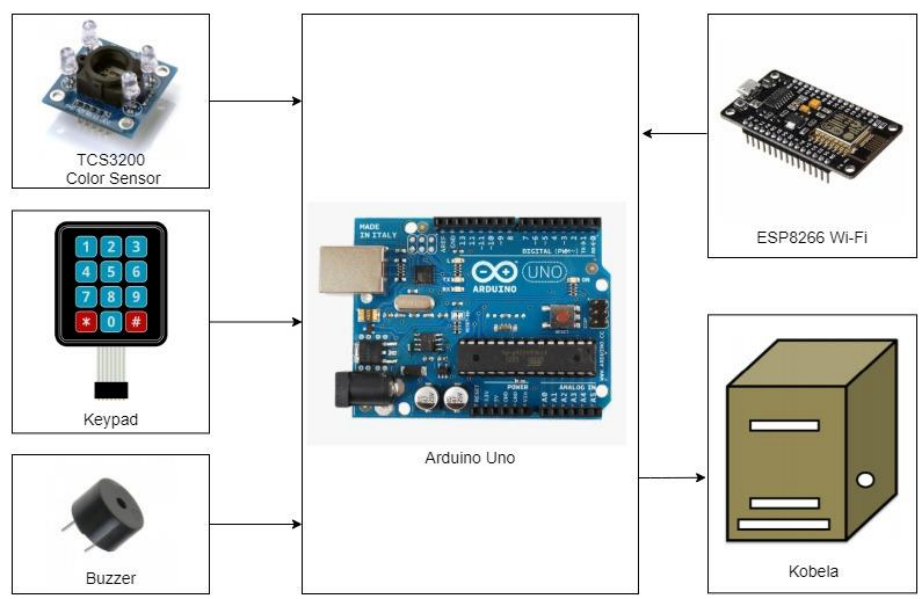

Figure 5. Block Diagram

Some of the devices in Figure 5 are arranged into a series of interconnected devices. Each of these devices has a function described in table 1 .

Table 1. Tool representation

\begin{tabular}{ll}
\hline \multicolumn{1}{c}{ Device } & \multicolumn{1}{c}{ Information } \\
\hline Arduino Uno & $\begin{array}{l}\text { Functions as a microcontroller to run the system from } \\
\text { Kobela props. }\end{array}$ \\
TCS3200 color sensor & $\begin{array}{l}\text { Function to detect color paper. } \\
\text { functions as an interface between the teacher and the } \\
\text { Keypad }\end{array}$ \\
Esp8266-01 & $\begin{array}{l}\text { Functions as a Wi-Fi module to send data to the } \\
\text { internet. }\end{array}$ \\
\hline
\end{tabular}

Muhammad Ilham Setiawan, Copyright (C2021, MIB, Page 1145 
Available Online at https://ejurnal.stmik-budidarma.ac.id/index.php/mib DOI 10.30865/mib.v5i3.3107

\begin{tabular}{ll}
\hline \multicolumn{1}{c}{ Device } & \multicolumn{1}{c}{ Information } \\
\hline buzzer & $\begin{array}{l}\text { Functions as an audible indicator when the color } \\
\text { sensor successfully takes a reading. } \\
\text { Kobela }\end{array}$ \\
\hline
\end{tabular}

\subsubsection{Testing Scenario}

The test scenario is carried out by testing the system functionality on the Kobel. The functionality of this device consists of hardware components that have each role to be tested as described in Table 2.

Table 2. System functionality

\begin{tabular}{lll}
\hline Component & \multicolumn{1}{c}{ Device } & \multicolumn{1}{c}{ Information } \\
\hline \multirow{3}{*}{ Hardware } & Arduino Uno & Testing the microcontroller can work according to the program. \\
& TCS3200 & Testing the workings of the sensors used to detect objects, namely \\
& color sensor & colored paper. \\
& Esp8266 Wi- & Test the Wi-Fi module whether data can be sent to the internet. \\
& Fi module & \\
\hline
\end{tabular}

System performance is measured using speed parameters and the accuracy of sensor readings. Sensor reading speed is the length of time a device takes when it receives instruction and processes it into an input. The accuracy of the sensor readings is taken from the comparison of the reading data on the Kobela teaching aid system with the actual data.

\section{RESULTS AND DISCUSSION}

This section discusses the test results that have been obtained from several experiments. Testing is divided into two, namely testing system functionality and system performance.

\subsection{Functionality}

Functionality testing was carried out on the hardware components of the Kobela props, namely Arduino Uno, color sensors, and Wi-Fi modules.

\subsubsection{Microcontroller Functionality}

Arduino Uno acts as a microcontroller which is the main controller on the system. The Arduino light in Figure 6 is red when the Arduino is successfully connected to the PC/laptop via USB cable.

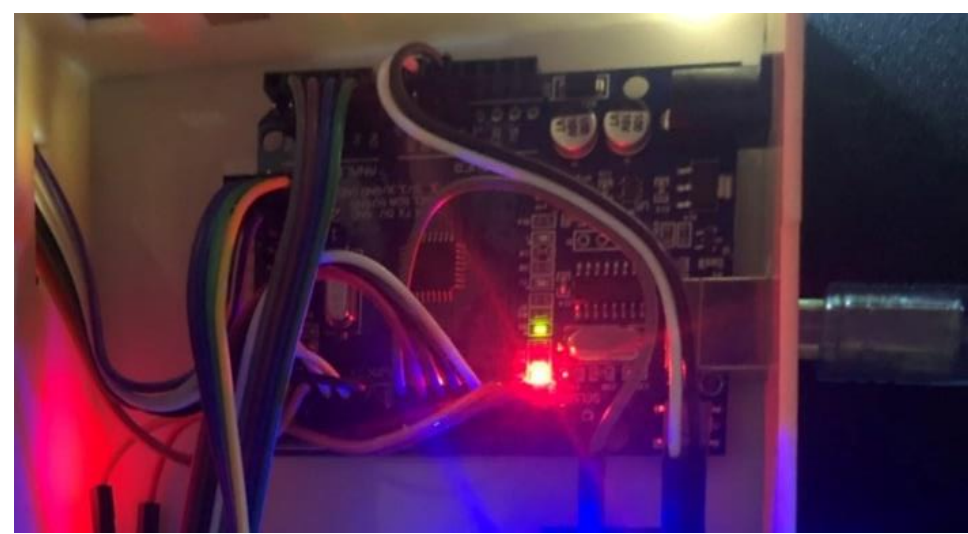

Figure 6. Arduino Uno Testing

\subsubsection{Color Sensor Functionality}

The TCS3200 color sensor is used to detect colors on color paper. This test can only be done using ten colored paper as shown in Figure 7. The colors used in this test include red, blue, royal blue, aqua, neon, green, purple, lavender, yellow, and orange. 
JURNAL MEDIA INFORMATIKA BUDIDARMA

Volume 5, Nomor 3, Juli 2021, Page 1142-1149

ISSN 2614-5278 (media cetak), ISSN 2548-8368 (media online)

Available Online at https://ejurnal.stmik-budidarma.ac.id/index.php/mib DOI 10.30865/mib.v5i3.3107

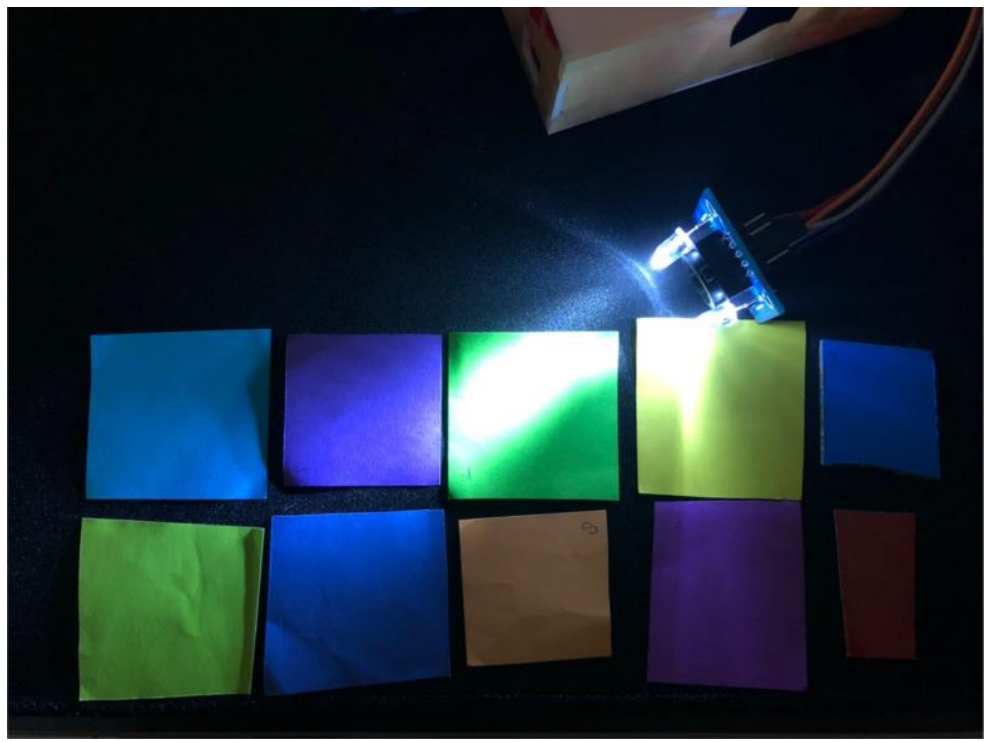

Figure 7. Color Sensor Testing Against Color Paper

\subsubsection{IoT Platform Functionality}

ESP8266 is used as a Wi-Fi module to transmit sensor data to the IoT platform via the internet. In Figure 8 the sensor data has been successfully sent. The IoT platform is ThingSpeak.
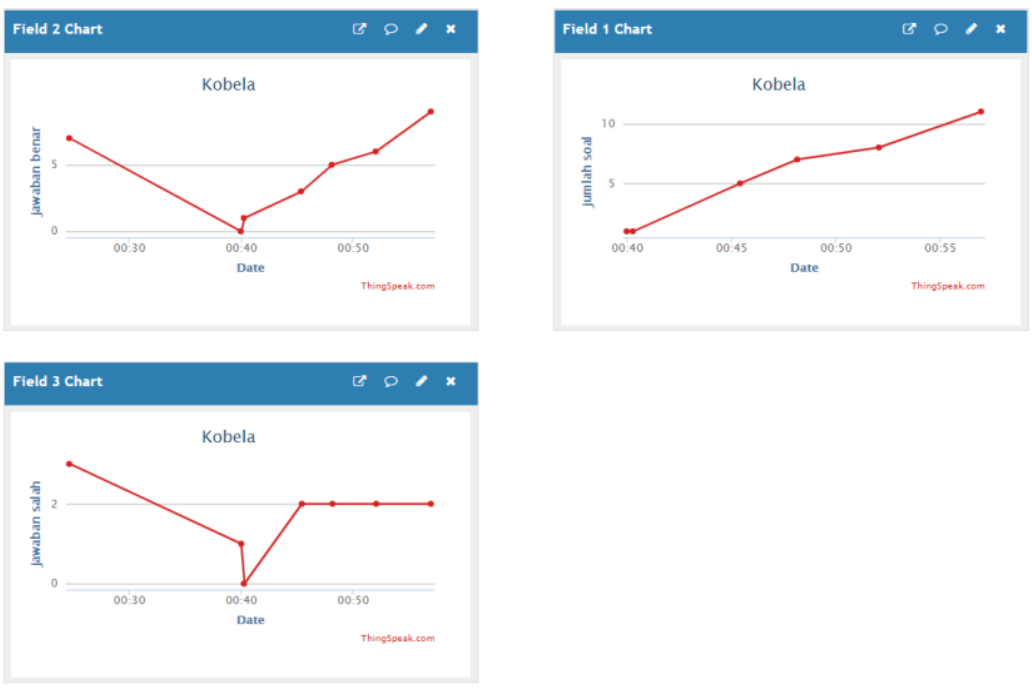

Figure 8. Sensor Reading

In Figure 8 there are three different graphs. The first graph, namely the field 1 chart, explains the number of questions that are read, starting at the 40th minute to the 55th minute, the number of questions that are read is 10 questions. The second graph, namely the field 2 chart, explains the number of readable answers, starting at the 40th minute to the 55th minute the number of correct answers that were successfully answered were 8 questions. The third graph, namely the field 3 chart, explains the number of incorrect answers, starting at the 40th minute to the 55th minute, the number of incorrect or unsuccessful answers being answered as many as 2 questions.

\subsection{Implementation Environment Condition}

Testing of the Kobela props was carried out by bringing the color paper closer to the sensor with a distance of \pm 5 $\mathrm{cm}$. If the distance between the color paper and the sensor is above $6 \mathrm{~cm}$, the color paper will not be read properly by the sensor. In addition to the sensor reading distance, the lighting conditions of the room also affect the success of the color sensor reading. When the sensor is placed in a bright room, the sensor cannot read the color paper properly. The sensor can make good readings in 8 Watt room lighting conditions. 
ISSN 2614-5278 (media cetak), ISSN 2548-8368 (media online)

Available Online at https://ejurnal.stmik-budidarma.ac.id/index.php/mib DOI 10.30865/mib.v5i3.3107

\subsection{System Performance Test Results}

System performance testing is done by doing several experiments. In one experiment there are 10 questions to be answered by each student.

\subsubsection{Reading Speed}

The results of testing the speed of sensor readings in one experiment can be seen in Table 3 .

Table 3. Sensor reading speed test table

\begin{tabular}{cccc}
\hline Sensor & No color paper & There is color paper & $\begin{array}{c}\text { Difference } \\
\text { (Millisecond) }\end{array}$ \\
\hline Sensor 1 & $00: 35: 41: 088$ & $00: 35: 48: 099$ & 7011 \\
Sensor 2 & $00: 42: 39: 021$ & $00: 42: 41: 045$ & 2024 \\
Sensor 3 & $00: 44: 11: 516$ & $00: 44: 14: 572$ & 3056 \\
Sensor 4 & $00: 46: 45: 705$ & $00: 46: 47: 768$ & 2063 \\
Sensor 5 & $00: 48: 13: 543$ & $00: 48: 14: 579$ & 1036 \\
Sensor 6 & $00: 53: 18: 080$ & $00: 53: 25: 159$ & 7079 \\
Sensor 7 & $00: 55: 39: 412$ & $00: 55: 40: 468$ & 1056 \\
Sensor 8 & $00: 56: 53: 625$ & $00: 56: 54: 716$ & 1091 \\
Sensor 9 & $00: 58: 11: 037$ & $00: 58: 15: 089$ & 4052 \\
Sensor 10 & $01: 00: 15: 217$ & $01: 00: 18: 229$ & 3012 \\
& & Average & 3148 \\
\hline
\end{tabular}

Based on the results of the reading speed test, the average speed is 3148 milliseconds or 3 seconds. In one experiment there were 10 questions given to students. The sensor reading speed of 3 seconds indicates that the time the device takes when receiving instruction in progress becomes an input for 3 seconds.

\subsubsection{Assessing Accuracy}

The results of testing the accuracy of assessing in ten trials can be seen in Table 4.

Table 4. The results of the assessment accuracy test

\begin{tabular}{cccc}
\hline Trial & $\begin{array}{c}\text { Number of } \\
\text { Correct } \\
\text { Answers }\end{array}$ & $\begin{array}{c}\text { Number of } \\
\text { Wrong } \\
\text { Answers }\end{array}$ & $\begin{array}{c}\text { Score }(1- \\
100)\end{array}$ \\
\hline 1 & 7 & 3 & 70 \\
2 & 9 & 1 & 90 \\
3 & 8 & 2 & 80 \\
4 & 8 & 2 & 80 \\
5 & 9 & 1 & 90 \\
6 & 9 & 1 & 90 \\
7 & 8 & 2 & 80 \\
8 & 8 & 2 & 80 \\
9 & 9 & 1 & 90 \\
10 & 9 & 1 & 90 \\
& & Average & 84 \\
\hline
\end{tabular}

Based on the performance test on the accuracy parameter, the assessment was carried out by giving 10 questions to students. The experiment was carried out 10 times and resulted in an average value of assessing the accuracy of 84 .

\section{CONCLUSION}

Based on the results of the analysis and implementation of the Kobela teaching aid system that utilizes IoT technology as a medium for assessing children's activities, it was found that the functionality of the system runs $100 \%$. All functions that exist in the system run according to the specified functionality. Based on the reading speed parameter, the average system delay time is 3 seconds with room lighting conditions of 8 Watts and the distance between the sensor and color paper is $\pm 5 \mathrm{~cm}$. This condition does not interfere with the testing process on the parameters of the accuracy rate. The results of testing the accuracy of assessing parameters obtained an average value of 84 .

\section{REFERENCES}

[1] A. Susanto, Teori Belajar dan Pembelajaran di Sekolah Dasar. Prenadamedia Group, 2016. 


\section{JURNAL MEDIA INFORMATIKA BUDIDARMA}

Volume 5, Nomor 3, Juli 2021, Page 1142-1149

ISSN 2614-5278 (media cetak), ISSN 2548-8368 (media online)

Available Online at https://ejurnal.stmik-budidarma.ac.id/index.php/mib

DOI 10.30865/mib.v5i3.3107

[2] A. M. Joenaidy, Konsep dan Strategi Pembelajaran di Era Revolusi Industri 4.0. Laksana, 2019.

[3] S. A. Octavia, Model-Model Pembelajaran. Deepublish, 2020.

[4] M. Suardi, Belajar \& Pembelajaran. Deepublish, 2018.

[5] Ridwan Abdullah Sani, Pembelajaran Berorientasi AKM: Asesmen Kompetensi Minimum. Bumi Aksara, 2021.

[6] Muhammad Hasan, T. Supatminingsih, and Sudirman, BELAJAR DAN PEMBELAJARAN. Media Sains Indonesia, 2020.

[7] S. Harnanto, "Alat Peraga Kotak Belajar Ajaib (Kobela) Dalam Pembelajaran Matematika Materi Perkalian Dan Pembagian Sekolah Dasar,” J. Ilm. Pendidik. Dasar UNISSULA, vol. 3, no. 1, pp. 33-42, 2016.

[8] V. Bhuvaneswari and R. Porkodi, "The internet of things (IOT) applications and communication enabling technology standards: An overview," Proc. - 2014 Int. Conf. Intell. Comput. Appl. ICICA 2014, no. October 2017, pp. 324-329, 2014.

[9] R. Adrami, "Pengaruh Media Kotak Ajaib Terhadap Motivasi Belajar Sejarah Siswa Kelas XI IPS SMA Negeri 1 Padang Tiji Kabupaten Pidie,” vol. 5, pp. 117-130, 2020.

[10] J. Gómez, J. F. Huete, O. Hoyos, L. Perez, and D. Grigori, "Interaction system based on Internet of things as support for education," Procedia Comput. Sci., vol. 21, pp. 132-139, 2013.

[11] I. N. Rahmanto, N. A. Suwastika, and R. Yasirandi, "How Can IoT Applicable to Practice Gross Motor Skill Through Hopscotch Game?," J. RESTI (Rekayasa Sist. dan Teknol. Informasi), vol. 4, no. 3, pp. 584-590, 2020.

[12] R. K. Jati, N. A. Suwastika, and R. Yasirandi, "Hopscotch Game to Support Stimulus in Children's Gross Motor Skill using IoT," Kinet. Game Technol. Inf. Syst. Comput. Network, Comput. Electron. Control, vol. 4, pp. 277-290, 2020.

[13] Seiba Shonia, N. A. Suwastika, and R. Yasirandi, "Bag Toss Game based on Internet of Education Things (IoET) for the Development of Fine Motor Stimulation in Children 5-6 Years Old," Emit. Int. J. Eng. Technol., vol. 8, no. 2, pp. 326 $345,2020$.

[14] H. Wajdi, N. A. Suwastika, and R. Yasirandi, "Iot architecture that supports the stimulation of gross motor development in children aged 5-6 years using drop box game," Regist. J. Ilm. Teknol. Sist. Inf., vol. 6, no. 2, pp. 119-129, 2020.

[15] D. Ratnawati and Vivianti, "Alat Pendeteksi Warna Menggunakan Sensor Warna Tcs3200 Dan Arduino Nano," Pros. Semin. Nas. Vokasi Indones., vol. 1, no. November, pp. 167-170, 2018.

[16] S. Pasha, "Thingspeak Based Sensing and Monitoring System for IoT with Matlab Analysis," Int. J. New Technol. Res., vol. 2, no. 6, pp. 19-23, 2016.

[17] R. Deekshath, P. Dharanya, K. R. D. Kabadia, G. D. Dinakaran, and S. Shanthini, "IoT Based Environmental Monitoring System using Arduino UNO and Thingspeak,” Int. J. Sci. Technol. Eng. |, vol. 4, no. 9, pp. 68-75, 2018. 